\title{
Supplementation Effect of Onion Peel Extracts on Small Intestine of Obese Mice
}

Jae-In Pak, Yoon-Woo Kim, Te-Su Seo and Aera Jang*

Department of Animal Products and Food Science, Kangwon National University, Chuncheon 200-701, Korea

Received August 11, 2012 /Revised November 8, 2012 /Accepted November 15, 2012

\begin{abstract}
This study was performed to determine the effect of onion peel extract using 70\% ethanol and $95 \%$ ethanol on its anti-oxidation activity, small intestine length, and intestinal villi of high-fat fed mice. Five percent of each onion peel extract using $70 \%$ and $95 \%$ ethanol showed significant decrease of E. coli and Listeria monocytogenes. Total phenolic contents of onion peel extracts using $70 \%$ and $95 \%$ ethanol were $166.89 \pm 0.03 \mathrm{mg} / \mathrm{g}$ and $160.89 \pm 0.13 \mathrm{mg} / \mathrm{g}$, respectively. In anti-oxidation activity, DPPH radical scavenging activity and SOD-like activity of onion peel extracts were higher at $100 \mathrm{ug} / \mathrm{ml}$ concentration. The obese mice were fed high-fat diets supplemented by 1,3 , and $5 \%$ of the onion peel extracts using $70 \%$ and $95 \%$ ethanol for 4 weeks. Body weight, feed intake, feed efficiency, small intestine weight, length, villi's length, and number of bacteria in intestine were determined. Body weight of mice fed $5 \%$ of onion extracts using both $70 \%$ and $95 \%$ ethanol was significantly lower than that of control $(p<0.05)$. However, feed intake was increased in mice fed $5 \%$ of onion extracts at both fermented ethanol levels. Small intestine weight and length of mice showed no significant change with supplementation of the onion peel extracts. However, length of small intestine villi was significantly longer than that of control. Total bacteria counts of $C$. Perfringenes and $E$. coli in small intestine of the mice were significantly reduced by supplementation of $5 \%$ of onion extract using ethanol, while lactic acid bacteria were increased. These results suggest that $5 \%$ of onion peel extracts using ethanol at either $70 \%$ or $95 \%$ concentration have potential to be used as an additive for body weight control and enhanced gut health; however, more research on its effectiveness is needed.
\end{abstract}

Key words : Onion peel, small intestine villi, ethanol, anti-oxidation, body weight

\section{서 론}

우리나라의 과거 식사패턴을 살펴보면 전통적으로 높은 당 질 섭취량에 의한 고 중성지방혈증이 많았다. 하지만 최근의 식생활은 생활수준의 향상과 더불어 활발한 세계적 교류를 통한 서구화로 인해, 육류 및 가공식품의 섭취가 증가하게 되 었고, 특히 동물성 식품의 섭취비율이 크게 증가하고 식물성 식품의 섭취비율이 상대적으로 감소함에 따라 비만에 의한 다양한 성인병이 문제가 되고 있다[17]. 우리나라의 2000년도 평균수명을 보면 75.9세로 나타난 반면에[9] 실제로 활동을 하 면서 건강하게 사는 기간을 나타내는 건강수명(Disability Adjusted Life Expectancy, DALE)은 67.8세로 세계 192개국 중 51위에 그쳐[34], 최근에는 얼마나 오래 사느냐에 대한 문제 보다는 얼마나 건강하게 오래 살 수 있는가에 대한 관심이 집중되고 있다. 이를 위해 여러 질병을 유발하는 인자들의 억 제 및 예방과 치료를 위한 건강기능식품에 대한 연구가 활발 히 이루어지고 있다[2].

양파(Allium cepa L)는 백합과에 속하는 다년생 식물로, 우

*Corresponding author

Tel : +82-33-250-8643, Fax : +82-33-251-7719

E-mail : ajang@kangwon.ac.kr
리 식생활에서 매우 중요한 조미료로 사용되며, 약재로도 널 리 사용되어왔다. 양파에는 quercetin, isorhamnetin, rutin 같 은 flavonoids가 풍부한 식품으로 알려져 있는데, flavonoids 는 diphenlyprogane (C6-C3-C6)의 골격을 가진 phenol계 화 합물의 총칭으로 과일, 야채, 견과류를 비롯한 식물의 줄기, 뿌리, 껍질에 널리 분포되어 있다[6,25]. 이러한 flavonoids는 allyl disulfide, diallyl disulfide 등의 생리활성 물질을 지니고 있어[7] 건강증진 목적으로 많은 연구 대상이 되고 있으며, 상 위에 제시된 화합물들은 항산화작용[15,20,27], 항균작용[19], 항암효과[22], low-density lipoprotein (LDL) 및 총지질에도 영향을 미친다고 알려져 있다[31]. 또한 양파는 종류에 따라 flavonol의 농도 변화가 큰데, 그 중 우리나라에서 존재하는 노란 양파의 경우 육질의 flavonol농도는 $60 \mathrm{mg} / \mathrm{kg}$ 에서 1,000 $\mathrm{mg} / \mathrm{kg}$ 의 범위를 나타낸다고 하였고, 색을 가진 마른 껍질에 특히 함량이 높아 2.5 6.5\%로 많은 양이 함유되어 있다고 알려 져 있다[4]. 우리나라와 같은 동양에서 사용되는 yellow onion 은 flavonoids중 quercetin의 함량이 상당히 높은데, 식물의 안쪽보다는 껍질이나 앞부분으로 갈수록 함량이 높아져 양파 육질 및 양파즙 중에는 $0.01 \%$, 양파껍질에는 순 무게의 $6.5 \%$ 에 이르고, 특히 색을 가진 마른 껍질에 함량이 높은 quercetin을 포함한다고 알려져 있다[12]. 그러나 양파껍질의 효능에도 불 
구하고 국내에서 생산되는 양파의 약 $10 \%$ 정도는 가공품으로 이용되고 있고, 양파를 가공할 때 발생하는 양파 가공 부산물 은 대부분 폐기 처분되고 있으며, 이와 같이 폐기되는 양파 가공 부산물의 $10 \%$ 정도는 껍질부분으로 대부분 퇴비로 사용 되는 실정이다[16]. 이러한 양파껍질에 대한 폐기는 생리활성 물질의 손실이 될 수 있고, 양파껍질을 이용한 연구는 폐자원 을 활용한다는 면에서 의미가 크다고 사료된다. 또한 현재까 지 진행된 양파 연구는 주로 육질만을 대상으로 수행 되었으 며 양파 껍질에 관한 연구는 많지 않다[2].

이에 본 연구는 양파에 대한 실험이 양파육질에 국한되어 폐기되는 양파껍질에 대한 이용 및 연구의 미흡한 점을 고려 하여, 첫 번째 실험에서는 병원성 미생물로 문제가 되고 있는 Escherichia Coli O157:H7, Salmonella Typhimurium, Listeria monocytogenes, Staphylococcus aureus 균주를 사용하여 항균활 성 효과를 알아보고 페놀성 함량분석, SOD 유사활성, DPPH radical 소거능, 환원력 측정을 통한 항산화 효과, 고지방 식이 급여가 ICR mouse의 소장 무게, 길이 및 소장융모의 길이를 측정하여 소화 흡수율 및 장내 미생물에 미치는 영향을 조사 하였다.

\section{재료 및 방법}

\section{양파껍질 추출물의 제조}

본 실험에 사용한 재료는 2011년 6월 국산 양파껍질을 구매 하여 수세하고 3 일간 말린 후, 분쇄기로 분쇄하였다. 분쇄된 시료 $400 \mathrm{~g}$ 은 각각 $70 \%$ 와 $95 \%$ 의 발효 주정 61 와 혼합하여 상온에서 24 시간 침지 후 추출물 용액을 진공 여과한 다음 얻어진 여액을 유기용매 분리형 rotary evaporator (EYELA, Japan)를 사용하여 $40^{\circ} \mathrm{C}$ 에서 농축한 후 냉장 $\left(4^{\circ} \mathrm{C}\right)$ 보관하여 시료로 사용하였다.

\section{양파껍질 추출물의 항 미생물 활성 검증}

\section{공시균주}

본 실험에 사용된 균주는 강원대학교 수의전염병학 실험실 에서 보관 중인 Escherichia Coli O157:H7 IVKB00014 KTCC13076, Salmonella Thphimurium KFRIO0251, Listeria monocytogenes K4-E22-L, Staphylococcus aureus KFRI240 균주를 분 양받아 Violet Red Bile Agar (VRBA), Salmonella and Shigella Agar (SS Agar), Listeria Enrichment Broth (LEB), Staphylococcus medium 110 을 이용하여 $37^{\circ} \mathrm{C}$ 에서 24 시간 계 대배양 하였다.

\section{미생물 성장억제 효과}

성장억제력은 평판 계수법을 사용하여 측정하였다. TSB (Tryptone Soya Broth, Oxoid) 배지에는 $9.9 \mathrm{ml}$ 에 각 균주를 $0.1 \mathrm{ml}$ 씩 첨가하여 2차 배양하고, 상위에 제시된 추출과정으로
얻어진 각각의 추출물들은 TSA (Tryptone Soy Agar, Oxoid) 배지에 0.2 와 $0.4 \%$ 의 농도로 첨가하여 멸균하였다. 각각의 균 주들은 희석액 $(0.1 \%$ peptone $\mathrm{G})$ 을 사용하여 희석된 각각의 균주는 petri dish에 $0.1 \mathrm{ml}$ 를 주입한 후, 멸균된 각각의 추출물 에 첨가 배지 $15 \mathrm{ml}$ 를 주입하였다. Petri dish는 흔들어 내용물 이 잘 혼합되도록 교반 후, $37^{\circ} \mathrm{C}$ incubator에서 24시간 배양한 다음, 각 배지의 집락형성단위(colony forming unit, $\mathrm{CFU}$ )를 측정하였다.

\section{항균활성 측정}

항균활성 측정은 inhibition zone test method에 따라 측정 하였다. 이들 균주의 생육을 위한 배지는 tryptone soy broth (Oxoid, England)와 tryptone soy agar (Oxoid, England)를 사용하였다. 각 추출물은 멸균된 paper disc $(\varnothing 8 \mathrm{~mm}$, Advantec, Japan)에 각각 $4,6,8 \mathrm{mg} / \mathrm{disc}$ 로 주입한 후, $40^{\circ} \mathrm{C}$ 에 서 30 분간 건조하였다. 멸균된 생육배지를 petri dish에 $15 \mathrm{ml}$ 씩 분주하여 응고시킨 후, 전 배양한 각 균주들은 응고된 배지 에 $0.1 \mathrm{ml}$ 씩 분주하여 무균적으로 도말한 다음, 사전에 추출물 을 주입 및 건조시킨 paper disc를 배지표면에 가볍게 놓고 $37^{\circ} \mathrm{C}$ incubator에서 24 시간 배양한 후, clear zone의 크기를 확인하였다.

\section{양파껍질 추출물의 항산화 활성 검증}

\section{항산화 시료 제조}

추출물을 $50 \%$ 발효주정으로 용해하여 10, 30, 50, $100 \mu \mathrm{g} /$ $\mathrm{ml}$ 의 농도가 되도록 제작하여 시료로 사용하였다.

\section{페놀성 화합물 함량 분석}

폴리페놀 화합물 함량은 Follin-Dennis의 방법을 사용하여 분석하였다. 증류수 $1.56 \mathrm{ml}$ 에 각각 농도로 희석된 추출물 40 1ㄹㄹㄹ 넣고, 2 N Follin-Ciocalteu's reagent (Sigma chemical Co., MO, USA) $100 \mu 1$ 를 주입하여 5 분간 반응시킨 다음, $20 \%$ sodium carbonate $300 \mu \mathrm{l}$ 첨가하고 $40^{\circ} \mathrm{C}$ 에서 30 분간 반응시켰 다. 반응 종료 후, 반응액의 흡광도를 $750 \mathrm{~nm}$ 에서 측정하고, gallic acid를 사용하여 검량곡선을 작성한 후 계산식에 활용하 였다.

\section{DPPH radical 소거능}

시료의 항산화 효과를 측정하기 위해 $\mathrm{DPPH}$ 에 대한 전자 공여능은 Abe 등[1]과 Yamaguchi 등[35]의 방법을 이용하여 측정하였다. $150 \mu \mathrm{M} \mathrm{DPPH}$ 용액 $1 \mathrm{ml}$ 에 농도별로 조제한 시료 $200 \mu 1$ 와 ethanol $800 \mu 1$ 를 혼합하고, vortex mixer로 10초간 진탕 한 후 $30^{\circ} \mathrm{C}$ 의 암실에서 30 분간 반응시켰다. 반응시킨 후 spectrophotometer 을 이용하여 $517 \mathrm{~nm}$ 에서 흡광도를 측정 하였고, 비교 항산화 물질로 ascorbic acid 를 이용하였다.

Superoxidase dismutase (SOD) 유사활성

SOD 유사활성은 Marklund와 Marklund의 방법[23]에 따 
라 시행하였다. 각 농도별로 희석한 시료 $0.2 \mathrm{ml}$ 에 tris- $\mathrm{HCl}$ buffer $3 \mathrm{ml}$ (50 mM trihydroxymethyl aminomethane, 10 $\mathrm{mM}$ EDTA, $\mathrm{pH} 8.5$ )와 $7.2 \mathrm{mM}$ pyrogallol $0.2 \mathrm{ml}$ 를 혼합하여 $25^{\circ} \mathrm{C}$ 에서 10 분간 반응시켰다. $1 \mathrm{~N} \mathrm{HCl} 1 \mathrm{ml}$ 로 반응 정지시킨 후 반응액 중 산화된 pyrogallol의 흡광도를 $420 \mathrm{~nm}$ 에서 측정 하였으며, 비교 항산화 물질로는 ascorbic acid를 같은 농도로 제조하여 SOD 유사활성을 비교하였다.

\section{환원력 측정}

양파껍질 추출물의 환원력은 Yen과 Chen [36]의 방법을 변 형하여 이용하였다. 각 농도별로 희석한 시료 $0.25 \mathrm{ml}$ 와 200 $\mathrm{mM}$ sodium phosphate buffer ( $\mathrm{pH}$ 6.6) $0.25 \mathrm{ml}$ 그리고 potassium ferricyaide $(10 \mathrm{mg} / \mathrm{ml}) 0.25 \mathrm{ml}$ 를 혼합하여 $50^{\circ} \mathrm{C}$ 에서 20 분간 반응시킨 후 TCA $(100 \mathrm{mg} / \mathrm{ml})$ 시약 $0.25 \mathrm{ml}$ 를 첨가하고 $1,350 \mathrm{rpm}$ 에서 15 분간 원심분리 하였다. 원심분리 후 상층액 $0.5 \mathrm{ml}$ 와 증류수 $0.5 \mathrm{ml}$ 그리고 $0.1 \%$ ferric chloride $0.1 \mathrm{ml}$ 를 혼합한 후 $700 \mathrm{~nm}$ 에서 흡광도를 측정하였다. 비교 항산화 물 질로는 ascorbic acid를 이용하였으며 환원력의 값은 흡광도 값으로 표시하였다.

\section{양파껍질 추출물의 비만쥐의 소화기관에 미치는 영향}

\section{실험동물 및 실험조건}

본 실험은 평균 체중 $15 \pm 1.2 \mathrm{~g}$ 인 4 주령의 암컷 ICR mouse를 SAMTAKO 에서 구입하여 사용하였다. 케이지 당 3마리로 총 7 개의 처리구로 하여 1 주 적응기간 후 사용하였고 4 주간 급여
하였고 사육조건은 dark/light 사이클은 각각 12시간, 온도는 $20 \pm 1{ }^{\circ} \mathrm{C}$, 습도는 $44 \sim 55 \%$ 으로 하여 사료와 음수는 무제한으로 급여하였다.

\section{사료섭취 및 제조}

사료는 SAMTAKO (한국)에서 구입한 고지방사료를 사용 하였으며, mouse에 lard가 함유된 고지방사료를 섭취시켜 비 만을 유도했다. 1 주일 후부터 실험 종료일까지 3주 동안은 고 지방사료(Control), $70 \%$ 주정 추출물 $1 \%$ 첨가 급여구(T1), $70 \%$ 주정 추출물 $3 \%$ 첨가 급여구(T2), $70 \%$ 주정 추출물 $5 \%$ 첨가 급여구(T3), $95 \%$ 주정 추출물 $1 \%$ 첨가사료(T4), $95 \%$ 주정 추출 물 3\% 첨가사료(T5), 95\% 주정 추출물 5\% 첨가사료(T6)를 제 조하여 이용하였다. 급여한 사료의 조성은 Table 1 과 같다.

\section{증체량 및 사료섭취량과 사료 요구율}

체중은 실험개시부터 28 일까지 매주 1 회 일정시간에 측정 하였다. 사료섭취량은 체중측정과 같이 측정하였고, 총 급여 량에서 잔량을 공제하여 구하였으며, 사료 요구율은 사료섭취 량을 증체량으로 나누어 계산하였다.

\section{소장 무게 및 소장 길이}

소장 무게 및 소장 길이는 사양실험 28 일령에 모든 처리구 를 해부하고 적출하여 각각 측정하였다.

\section{소장 villi 길이}

소장 villi 길이 사양실험 28 일에 소장을 적출하여 $0.2 \mathrm{M} \mathrm{PBS}$ (Phosphate Buffer Solution, pH7.4)으로 희석한 10\% formalin

Table 1. High fat diet fornula for ICR-mouse

\begin{tabular}{lccccccc}
\hline \multirow{2}{*}{ Items } & $\mathrm{mg}$ & \multicolumn{3}{c}{$\mathrm{mg}(70 \%$ EtOH $)$} & \multicolumn{3}{c}{$\mathrm{mg}(95 \%$ EtOH $)$} \\
\cline { 2 - 7 } & $\mathrm{C}^{1)}$ & $\mathrm{T} 1$ & $\mathrm{~T} 2$ & $\mathrm{~T} 3$ & $\mathrm{~T} 4$ & $\mathrm{~T} 5$ & $\mathrm{~T} 6$ \\
\hline Casein, 80 Mesh & 200 & 200 & 200 & 200 & 200 & 200 & 200 \\
L-Cystine & 3 & 3 & 3 & 3 & 3 & 3 & 3 \\
Corn Starch & 0 & 0 & 0 & 0 & 0 & 0 & 0 \\
Maltodextrin 10 & 125 & 125 & 125 & 125 & 125 & 125 & 125 \\
Sucrose & 68.8 & 68.8 & 68.8 & 68.8 & 68.8 & 68.8 & 68.8 \\
Cellulose, BW200 & 50 & 50 & 50 & 50 & 50 & 50 & 50 \\
Soybean Oil & 25 & 25 & 25 & 25 & 25 & 25 & 25 \\
Lard* & 245 & 245 & 245 & 245 & 245 & 245 & 245 \\
Mineral Mix, S10026 & 10 & 10 & 10 & 10 & 10 & 10 & 10 \\
Dicalcium Phosphate & 13 & 13 & 13 & 13 & 13 & 13 & 13 \\
Calcium Carbonate & 5.5 & 5.5 & 5.5 & 5.5 & 5.5 & 5.5 & 5.5 \\
Potassium Citrate & 16.5 & 16.5 & 16.5 & 16.5 & 16.5 & 16.5 & 16.5 \\
Vitamin Mix, V10001 & 10 & 10 & 10 & 10 & 10 & 10 & 10 \\
Choline Bitartrate & 2 & 2 & 2 & 2 & 2 & 2 & 2 \\
FD\&C Blue Dye \#1 & 0.05 & 0.05 & 0.05 & 0.05 & 0.05 & 0.05 & 0.05 \\
Onion Peel Extract $(\%)$ & 0 & 7.7 & 23.2 & 38.7 & 7.7 & 23.2 & 38.7 \\
Total & 773.85 & 781.55 & 797.05 & 812.55 & 781.55 & 797.05 & 812.55 \\
\hline
\end{tabular}

${ }^{1)} \mathrm{C}$ : high fat diet fed group, T1: $1 \%$ of $70 \%$ EtOH extract with high fat diet, T2: $3 \%$ of $70 \%$ EtOH extract with high fat diet, $\mathrm{T} 3$ : $5 \%$ of $70 \%$ EtOH extract with high fat diet, T4: 1\% of 95\% EtOH extract with high fat diet, T5: 3\% of 95\% EtOH extract with high fat diet, T6: $5 \%$ of $95 \%$ EtOH extract with high fat diet 
으로 고정하고, microtome (Clinicut 60 Cryostat, Bright Co. Ld., England)으로 $10 \mu \mathrm{m}$ 두께로 $40^{\circ} \mathrm{C}$ 에서 절편 하였다. 절편 은 $\mathrm{HE}$ 염색(Hematoxylin Eosin stain)후 micrometer를 광학현 미경에 장착하여 소장 villi의 길이를 측정하였다.

\section{장내 미생물 검사}

장내 미생물 검사는 사양실험 28 일령에 적출한 맹장 내용물 을 각각 $1 \mathrm{~g}$ 씩 채취하여 $0.9 \% \mathrm{NaCl}$ 용액 $99 \mathrm{ml}$ 에 homogenizer 로 60 초간 균질시키고, 그 현탁액을 $0.1 \%$ peptone (Pancreatic digest of Gelatin)용액 $9 \mathrm{ml}$ 에 연속 희석시켰으며, $9 \mathrm{ml}$ 에 희석 할 때는 vortex mixer로 20 초간 처리하였다. 위의 희석액은 $\mathrm{TSA}, \mathrm{TSC}, \mathrm{MRS}, \mathrm{VRBA}$ 배지에 $0.1 \mathrm{ml}$ 분주 하여 $37^{\circ} \mathrm{C}$ 배양기 에서 24시간 배양 후, 각 배지의 집락형성단위(colony forming unit, $\mathrm{CFU}$ )를 측정하였다.

\section{통계처리}

본 실험에서 얻어진 결과는 SPSS 19.0 (SPSS INC., Illinois, USA)을 이용하여 ANOVA로 분석하였고, 처리 평균 간의 유 의성 검증은 Duncan's multiple range test로 검증하였으며 $p<0.05$ 이상일 때 통계적 유의성이 있는 것으로 판단하였다 [30]. 모든 분석항목은 3 회 이상 반복 시험하여 결과는 mean $\pm \mathrm{SD}$ 값으로 나타내었다.

\section{결과 및 고찰}

\section{양파껍질 추출수율}

페놀성 화합물은 식물계에 널리 분포되어 있는 2 차 대사산 물의 하나로서 다양한 구조와 분자량을 가지며, 이들은 phenolic hydroxyl기를 가지고 있기 때문에 단백질 등의 거대분자 들과 결합하는 성질을 가지며, 항산화 효과 등의 생리활성 기 능도 가진다[21]. 양파껍질 분말로부터 이러한 페놀성 화합물 들을 얻기 위해 $70 \%$ 및 $95 \%$ 발효주정을 추출용매로 하여 추출 한 수율은 각각 $5.79 \%, 3.56 \%$ 로 $70 \%$ 발효주정의 추출 수율이 $2 \%$ 이상 높게 나타났다(data not shown).

\section{양파껍질 추출물의 항 미생물 활성 검증 결과}

\section{미생물 성장억제 효과}

양파껍질 $70 \%$ 및 95\% 발효주정 추출물에 대한 병원성 미생
물에 대한 성장억제력 결과는 Table 2에 나타난 바와 같다. 모든 병원성 균주들이 대조군에 비해 발효주정추출물의 처리 에 따라 미생물의 성장을 억제하는 것으로 나타났다. 그 중 그람 음성균에서는 Escherichia coli, 그람 양성균에서는 Listeria monocytogenes가 $95 \%$ 발효주정 추출물이 가장 높은 성장억제 력을 나타냈으며, 그 중 Escherichia coli에 대해 가장 높은 성장 억제력을 나타냈다. Escherichia coli는 온혈 동물의 장관에서 많이 볼 수 있는 박테리아로써, 대부분 대장균의 변종은 해롭 지 않지만, 항원형 O157:H7 등은 사람의 식중독을 일으키며, 가끔 대규모의 식품 리콜의 원인이 된다[33]. 상위에 제시된 결과로 미루어 보았을 때, 양파껍질 추출물은 동물이나 인간 의 장관에 있어서 생리 활성적 역할을 할 수 있고, 특히 동물에 게 있어서는 사료로 첨가하여 섭취시켰을 때, 소화기관 및 장 내에 유익한 결과를 가져올 수 있을 것으로 사료된다.

\section{양파껍질 추출물의 항산화 활성 검증}

\section{페놀성 화합물 함량 분석결과}

페놀은 식물과 식품에 널리 존재하여 항산화 효과 및 방어 기작 등의 중요한 역할을 하는 것으로 잘 알려져 있다. 식물체 에서 총 페놀 함량을 측정하는 다양한 방법들 중 실험 과정이 빠르고, 간단하며, 결과가 정확한 Folin-Denis법은 페놀성 물 질이 phosphomolybdic acid와 반응하여 청색으로 발광하는 현상을 이용하여 식물체 중의 총 페놀 함량을 측정하는 방법 이다. 각 $70 \%$ 와 $95 \%$ 주정 추출물의 페놀함량은 각각 $166.89 \pm$ $0.03 \mathrm{mg} / \mathrm{g}, 160.89 \pm 0.13 \mathrm{mg} / \mathrm{g}$ 을 보여 70\% 주정 추출물에서 페놀함량이 높게 추출되어 경제적인 가치가 있을 것으로 판단 된다(Table 3).

\section{$\mathrm{DPPH}$ radical 소거능 결과}

지질과산화의 연쇄반응에 관여하는 항산화 물질은 산화성 유리기와 반응함으로써 안정한 유리기인 1.1-diphenyl1-

Table 3. Total phenolics content of each ethanol extract from onion peel (unit: $\mathrm{mg} / \mathrm{g}$ )

\begin{tabular}{lcc}
\hline & $70 \% \mathrm{EtOH}$ & $95 \% \mathrm{EtOH}$ \\
\hline Total phenolics content & $166.89 \pm 0.03^{\mathrm{a}}$ & $160.89 \pm 0.13^{\mathrm{b}}$ \\
\hline
\end{tabular}

${ }^{\mathrm{a}-\mathrm{b}} \mathrm{Mean} \pm \mathrm{SD}$ in the same column with different superscripts are significantly different at $p<0.05$.

Table 2. The growth inhibition effect of onion peel extract by EtOH

\begin{tabular}{lccc}
\hline \multirow{2}{*}{ Pathogenic bacteria } & \multicolumn{3}{c}{ Log CFU/ml } \\
\cline { 2 - 3 } & Control & $70 \%$ EtOH & $95 \%$ EtOH \\
\hline Escherichia coli O157:H7 & $6.43 \pm 0.02^{\mathrm{a}}$ & $5.67 \pm 0.05^{\mathrm{b}}$ & $5.02 \pm 0.02^{\mathrm{c}}$ \\
Salmonella Typhimurium & $6.74 \pm 0.01^{\mathrm{a}}$ & $5.97 \pm 0.02^{\mathrm{b}}$ & $5.92 \pm 0.04^{\mathrm{b}}$ \\
Listeria monocytogenes & $5.82 \pm 0.04^{\mathrm{a}}$ & $5.44 \pm 0.03^{\mathrm{ab}}$ & $5.28 \pm 0.02^{\mathrm{b}}$ \\
Staphylococcus aureus & $6.93 \pm 0.07^{\mathrm{a}}$ & $6.28 \pm 0.03^{\mathrm{b}}$ & $6.21 \pm 0.02^{\mathrm{b}}$ \\
\hline
\end{tabular}

${ }^{\mathrm{a}-\mathrm{c}} \mathrm{Mean} \pm \mathrm{SD}$ in the same row with different superscripts are significantly different at $p<0.05$. 
2-picryl hydrazyl (DPPH)을 hydrazine 형태로 환원시키는 능 력이 있다[5]. 또한 DPPH는 hydrazyl의 질소원자가 불안정한 상태에 있으므로 쉽게 항산화성 물질과 반응하여 수소원자를 받아들이고 자체의 정색성을 잃는다. 이러한 성질을 이용하여 $\mathrm{DPPH}$ radical 소거능은 매우 간단히 항산화능을 측정할 수 있으므로 $\mathrm{DPPH}$ 의 흡광도를 감소시키는 정도로 항산화력을 측정할 수 있다.

양파껍질을 $70 \%$ 및 $95 \%$ 주정으로 추출한 추출물의 $\mathrm{DPPH}$ radical 소거능은 처리 농도 의존적으로 증가하는 경향을 보였 고, 비교 항산화 물질인 ascorbic acid가 10, 30, 50, $100 \mu \mathrm{g} /$ $\mathrm{ml}$ 농도에서의 DPPH radical 소거능 보다는 모두 낮은 값을 나타냈다. 그 중 $70 \%$ 및 $95 \%$ 주정 추출물 $100 \mathrm{\mu g} / \mathrm{ml}$ 에서 각각 $61.86 \%, 60.21 \%$ 의 억제력을 보였으나 주정 추출물간의 차이는 보이지 않았다(Fig. 1).

\section{Superoxidase dismutase (SOD) 유사활성 결과}

생체내 항산화 효소 중 하나인 $\mathrm{SOD}$ 는 세포 내 활성산소를 과산화수소로 전환시키는 반응을 촉매 하는 효소이며 SOD에 의해 생성된 과산화수소는 catalase 또는 peroxidase에 의해 물 분자와 산소분자로 전환되는 중요한 효소 중에 하나이다. $\mathrm{SOD}$ 유사활성 물질은 효소는 아니지만 주로 phytochemical에 속하는 저분자물질이 SOD와 유사한 역할을 하여 superoxide 의 반응성을 억제하며 superoxide로부터 생체를 보호한다고 알려져 있다. 따라서 SOD 유사활성을 갖는 물질은 인체내의 superoxide를 제거함으로써 노화억제와 더불어 산화적 장애

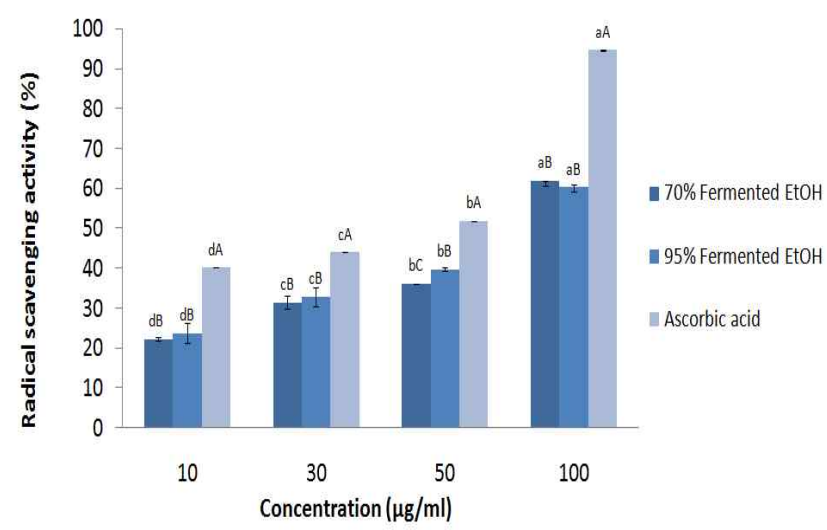

Fig. 1. DPPH radical scavenging activity of activity of onion peel extract with EtOH.
의 방어효과를 가진다[29]. 양파껍질을 $70 \%$ 및 $95 \%$ 주정으로 추출한 추출물의 SOD 유사활성을 측정한 결과 모든 추출물의 값은 농도 의존적으로 증가하는 경향을 보였으나 비교 항산화 물질인 ascorbic acid의 SOD 유사활성 보다는 모두 낮은 값을 나타냈다. 그 중 70\% 및 95\% 주정 추출물 농도 $100 \mathrm{\mu g} / \mathrm{m}$ 에서 각각 $60.93 \%$ 과 $61.26 \%$ 를 보였으나 유의적인 차이는 없었다 (Fig. 2).

\section{환원력 측정 결과}

환원력은 reductones가 제공하는 수소원자가 free radical 의 사슬을 분해함으로써 시작되며 따라서 reducing power는 첨가되는 시료의 농도변화에 따라 큰 변화를 나타내고, 흡광 도의 값 자체가 시료의 환원력을 나타낸다[10]. Table 4 는 양파 껍질 추출물이 농도에 따라 철 이온을 $\mathrm{Fe}^{3+}$ 에서 $\mathrm{Fe}^{2+}$ 로 환원시 키는 환원력을 흡광도로 측정한 결과이다. 양파껍질을 $70 \%$ 및 $95 \%$ 주정으로 추출한 추출물의 환원력 측정결과 $70 \%$ 주정 추출물은 $100 \mu \mathrm{g} / \mathrm{ml}$ 에서 대조군에 비해 환원력이 증가함을 나타내었으며 비교항산화 물질인 Vit. C와 유사한 활성을 나 타내었다. $95 \%$ 주정 추출물에서는 모든 추출물 농도가 비교 항산화 물질인 ascorbic acid에 비해 높은 값들을 보였고, 그 중 추출물 농도 $100 \mu \mathrm{gg} / \mathrm{ml}$ 가 $0.9750 \pm 0.1100 \mu \mathrm{gg} / \mathrm{ml}$ 로 가장 높 은 값을 나타냈다. 이는 Park 등이 머루종실을 에탄올로 추출 하여 $100 \mu \mathrm{g} / \mathrm{ml}$ 농도에서 측정한 환원력과[26], Nam 등의 두류를 에탄올로 추출하여 측정한 환원력[24]보다도 더 높은 값을 나타냈다.

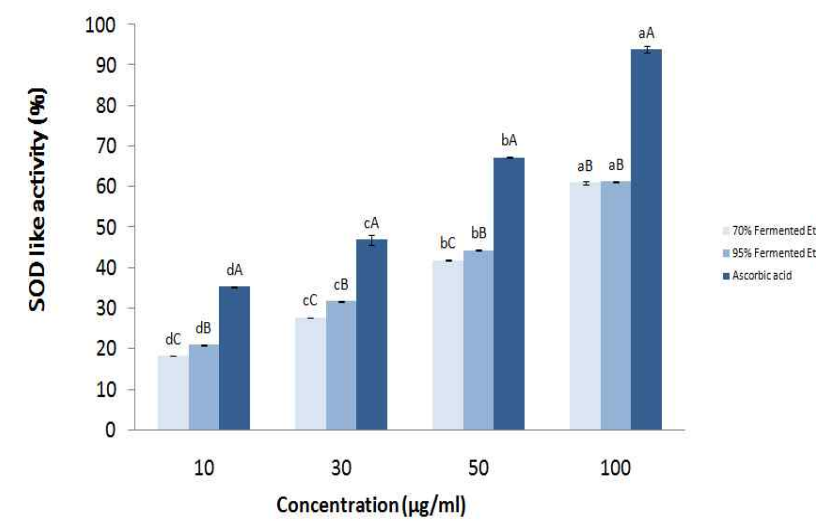

Fig. 2. SOD like activity of onion peel extract with $70 \%$ and 95\% EtOH.

Table 4. Reducing power of each extract from onion peel (unit: $\mu \mathrm{g} / \mathrm{g}$ )

\begin{tabular}{lcccc}
\hline \multirow{2}{*}{ Extract } & \multicolumn{4}{c}{ Concentration $(\mu \mathrm{g} / \mathrm{ml})$} \\
\cline { 2 - 5 } & 10 & 30 & 50 & 100 \\
\hline $70 \%$ EtOH & $0.50 \pm 0.046^{\mathrm{bB}}$ & $0.53 \pm 0.019^{\mathrm{abB}}$ & $0.56 \pm 0.077^{\mathrm{abB}}$ & $0.60 \pm 0.025^{\mathrm{aB}}$ \\
$95 \%$ EtOH & $0.70 \pm 0.251^{\mathrm{bA}}$ & $0.75 \pm 0.122^{\mathrm{bA}}$ & $0.76 \pm 0.463^{\mathrm{bA}}$ & $0.98 \pm 0.110^{\mathrm{aA}}$ \\
Ascorbic acid & $0.53 \pm 0.018^{\mathrm{aB}}$ & $0.56 \pm 0.144^{\mathrm{aB}}$ & $0.57 \pm 0.072^{\mathrm{aB}}$ & $0.60 \pm 0.052^{\mathrm{aB}}$ \\
\hline
\end{tabular}

${ }^{\mathrm{a}-\mathrm{c}}$ Mean $\pm \mathrm{SD}$ in the same row with different superscripts are significantly different at $p<0.05$.

${ }^{\mathrm{A}-\mathrm{B}} \mathrm{Mean} \pm \mathrm{SD}$ in the same column with different superscripts are significantly different at $p<0.05$. 
위의 결과를 바탕으로 양파껍질추출물은 DPPH radical 소 거능, SOD 유사활성의 측정결과에서는 Vit. C 만큼 뛰어난 항산화 능력을 발휘하지는 못했지만 농도의존적으로 증가하 는 효과를 나타내었다. 또한 환원력 실험결과 Vit. C보다 더 높은 항산화 능력을 나타냈고, 총 페놀함량을 포함하여 양파 껍질 추출물을 통한 모든 항산화 활성이 높은 것으로 측정되 어 앞으로 양파껍질을 이용하여 제조한 여러 식품, 사료는 인 간 및 동물에게 있어 항산화제로서 기능을 발휘할 것이라고 기대된다.

\section{양파껍질 추출물이 비만쥐의 소화기관에 미치는 영향}

\section{증체량, 사료섭취량 및 사료효율 결과}

양파껍질 추출물을 농도별로 고지방사료에 첨가하여 ICR mouse에 급여한 후 증체량, 사료섭취량 및 사료효율의 결과는 Table 5와 같다. 증체량은 추출물 농도에 따라 농도 의존적으 로 감소하였다 $(p \times 0.05)$. 이러한 결과는 $\mathrm{Kim}$ 등이 보고하는 naringin, hesperidin 등의 flavonoids 급여시 체중이 감소한다 는 결과[18]와 유사하였고 이들은 분변으로 지방배설을 증가 시켜 체중이 감소하는 것으로 결론지어 본 연구에서도 양파껍 질 추출물을 첨가한 사료의 섭취는 체중조절기능이 있는 것으 로 판단된다.

그 중 사료섭취량은 $70 \%$ 주정 5\% 처리구와 95\% 주정 5\% 처리구가 각각 $4.24 \mathrm{~g} / \mathrm{day}, 4.57 \mathrm{~g} / \mathrm{day}$ 을 보여 대조구보다 증

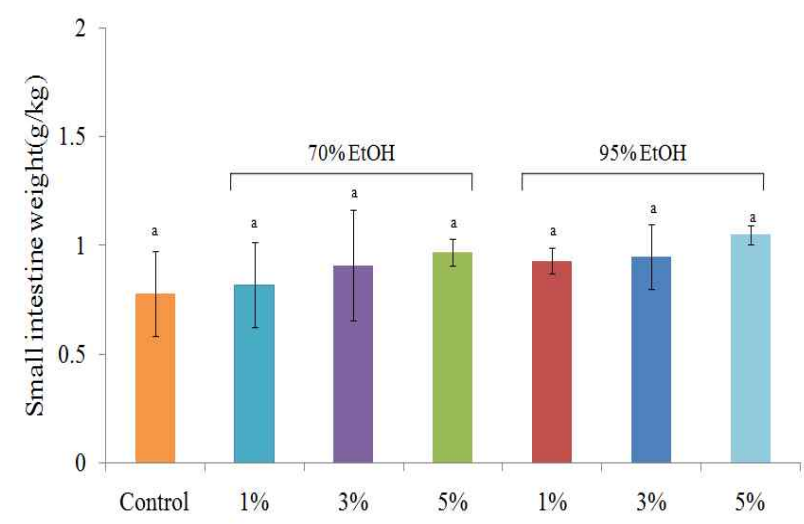

Fig. 3. Effects of onion peel extracts supplementation on small intestine weight of mouse fed high fat diet.
가하였음을 나타내었고 사료 효율도 0.22 와 0.20 으로 각각 대 조구에 비해 가장 낮은 값을 보였다. 반면에 일일 증체량은 $70 \%$ 주정 $5 \%$ 처리구와 $95 \%$ 주정 $5 \%$ 처리구가 각각 $0.93 \mathrm{~g}$, $0.90 \mathrm{~g}$ 으로 각각 대조구에 비해 유의적으로 가장 낮은 값을 나타냈다. 이러한 결과는 상위에 제시된 체중측정 결과와 더 불어 양파껍질 추출물을 동물에게 섭취시킬 경우, 사료섭취량 과 효율이 좋음에도 불구하고 증체량이 증가하지 않으므로, 경제동물 사양을 위한 사료소재로서의 이용은 다소 효율이 떨어진다고 사료된다. 하지만 인체에 있어서는 양파껍질을 가 공하여 섭취할 경우 체중을 조절을 위한 다이어트 식품으로써 의 효과가 기대된다[3].

\section{소장 무게 및 길이 측정 결과}

양파껍질 추출물을 농도별로 고지방사료에 첨가하여 ICR mouse 에 급여한 후 소장의 무게 및 길이측정 결과는 각각 Fig. 3 과 4 와 같다. 소장의 무게 측정 결과 $70 \%$ 와 $95 \%$ 주정 추출물의 모든 처리구에서 농도 의존적으로 값이 증가하는 경향을 보여 $70 \%$ 주정 추출물 $5 \%$ 처리구와 $95 \%$ 주정 추출 물 $5 \%$ 처리구가 각각 $0.97 \pm 0.06 / \mathrm{kg}, 1.05 \pm 0.04 / \mathrm{kg}$ 을 나타 내었으나 유의적인 차이는 보이지 않았다. 소장의 길이 또한 $70 \%$ 주정 추출물 5\% 처리구와 95\% 주정 추출물 5\% 처리구 에서 각각 $38.00 \pm 1.73 \mathrm{~m}, 39.33 \pm 4.04 \mathrm{~m}$ 로 각 용매의 최고 추 출물 첨가농도 처리구들이 대조구에 비해 긴 길이를 나타냈 으나 유의적인 차이는 없었다. Poksay 등은 식이섬유를 섭

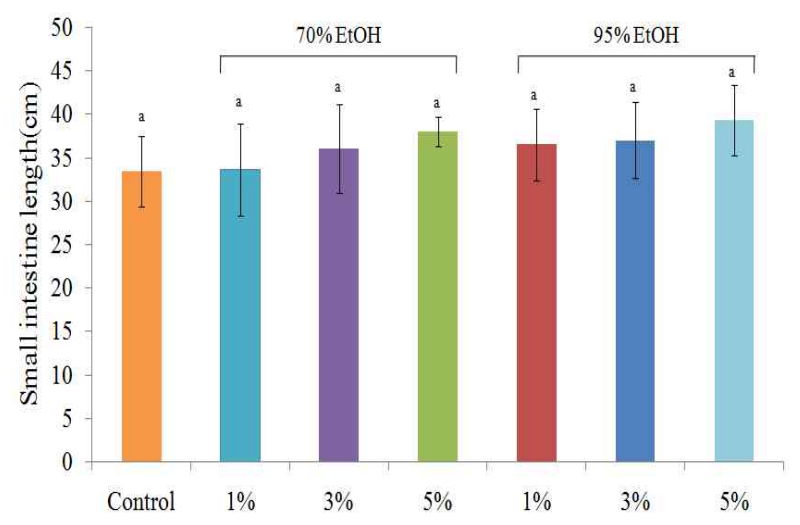

Fig. 4. Effects of onion peel extracts supplementation on small intestine length of mouse fed high fat diet.

Table 5. Effects of onion peel extracts supplementation on body weight gain (g), feed intake, feed efficient ratio in high fat fed mouse

\begin{tabular}{lccccccc}
\hline \multirow{2}{*}{ Items } & \multicolumn{3}{c}{ Treatments $^{1)}$} \\
\cline { 2 - 7 } & \multirow{2}{*}{ Control } & \multicolumn{3}{c}{$70 \%$ EtOH } & \multicolumn{3}{c}{$95 \%$ EtOH } \\
\cline { 2 - 7 } & & $1 \%$ & $3 \%$ & $1 \%$ & $3 \%$ & $5 \%$ \\
\hline Weight gain (g) & $1.05 \pm 0.10^{\mathrm{a}}$ & $0.97 \pm 0.39^{\mathrm{b}}$ & $0.96 \pm 0.27^{\mathrm{b}}$ & $0.93 \pm 0.06^{\mathrm{bc}}$ & $1.04 \pm 0.09^{\mathrm{a}}$ & $0.94 \pm 0.08^{\mathrm{bc}}$ & $0.90 \pm 0.03^{\mathrm{c}}$ \\
Feed intake $(\mathrm{g} / \mathrm{d})$ & $3.88 \pm 0.06^{\mathrm{c}}$ & $4.21 \pm 0.05^{\mathrm{b}}$ & $4.20 \pm 0.06^{\mathrm{b}}$ & $4.24 \pm 0.07^{\mathrm{b}}$ & $4.57 \pm 0.05^{\mathrm{a}}$ & $4.24 \pm 0.09^{\mathrm{b}}$ & $4.57 \pm 0.08^{\mathrm{a}}$ \\
FER & 0.27 & 0.23 & 0.23 & 0.22 & 0.23 & 0.22 & 0.20 \\
\hline
\end{tabular}

${ }^{\mathrm{a}-\mathrm{c}}$ Mean \pm SD in the same column with different superscripts are significantly different at $p<0.05$. 
취했을 때 장기의 증식이 촉진된다고 하였고[28], Ikegami 등 과 Song 등은 식이섬유를 투여하면 소장의 무게와 길이가 증가한다고[13,32] 보고했는데 본 연구에서는 양파껍질 추출 물의 급여가 소장의 무게 증가에 미치는 영향에는 유의적인 차이를 보이지 않았다.

\section{소장 villi 특성}

양파껍질 추출물을 농도별로 고지방사료에 첨가하여 ICR mouse에 급여한 후 소장의 융모길이 측정 결과는 Fig. 5 와 같다. $70 \%$ 와 $95 \%$ 주정 추출물을 $5 \%$ 급여했을 때 소장 villi의 길이가 각각 $52.40 \pm 4.70 \mu \mathrm{m}, 52.80 \pm 4.44 \mu \mathrm{m}$ 으로 각 용매의 최 고 추출물 첨가농도 처리구들이 대조구에 비해 가장 큰 유의
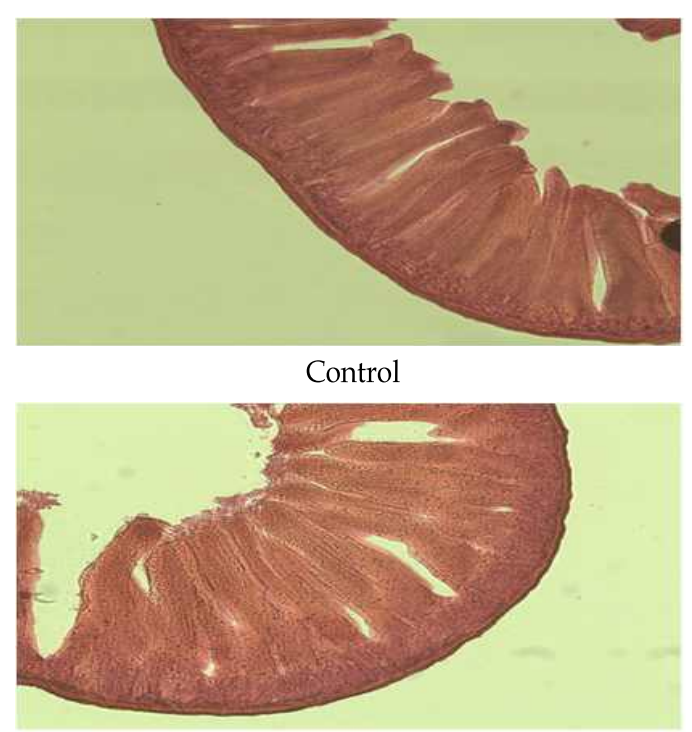

$3 \%$ supplementation of $70 \% \mathrm{EtOH}$

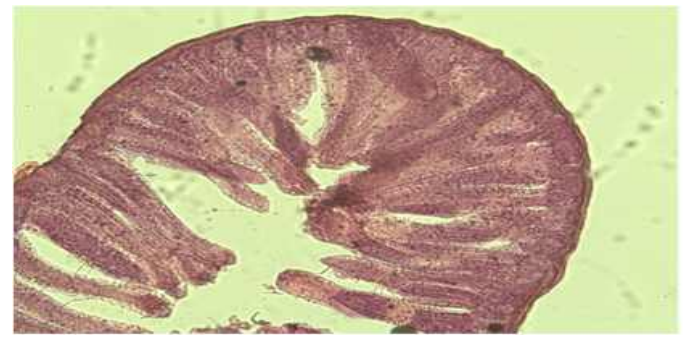

$1 \%$ supplementation of $95 \% \mathrm{EtOH}$

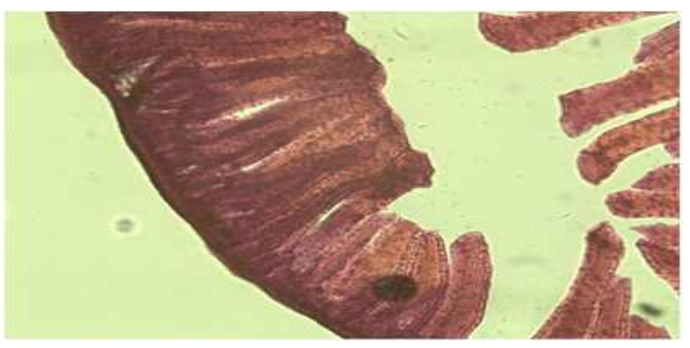

$5 \%$ supplementation of $95 \% \mathrm{EtOH}$

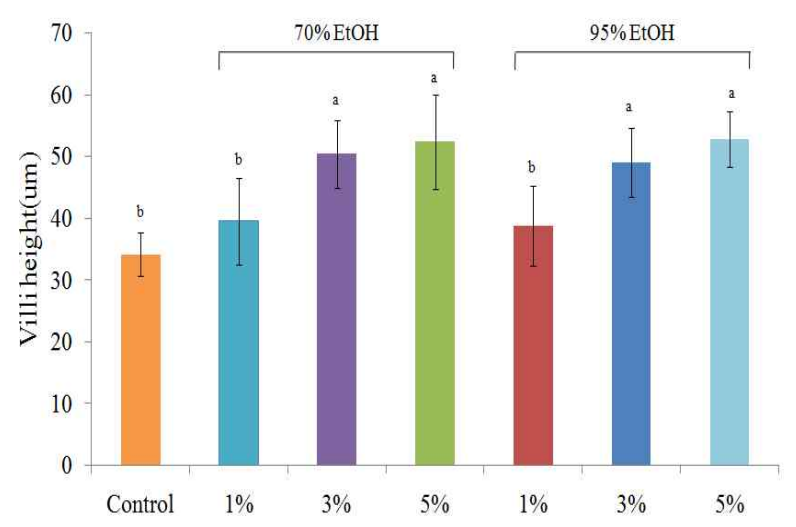

Fig. 5. Effects of onion peel extracts supplementation on small intestine villi height of mouse fed high fat diet.

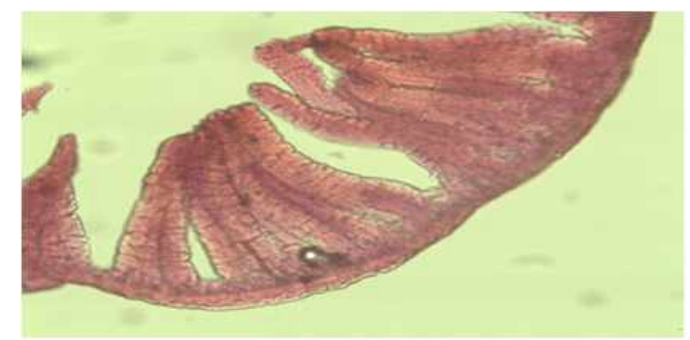

$1 \%$ supplementation of $70 \% \mathrm{EtOH}$

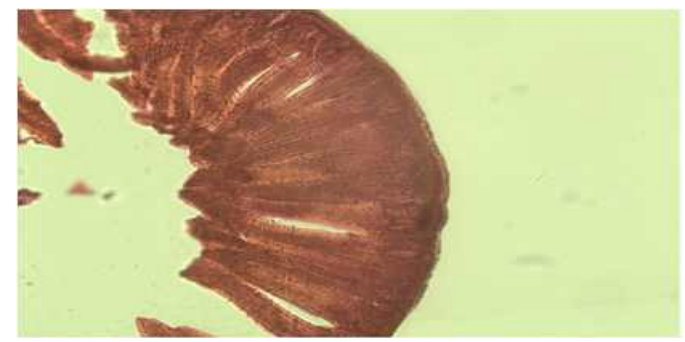

$5 \%$ supplementation of $70 \% \mathrm{EtOH}$

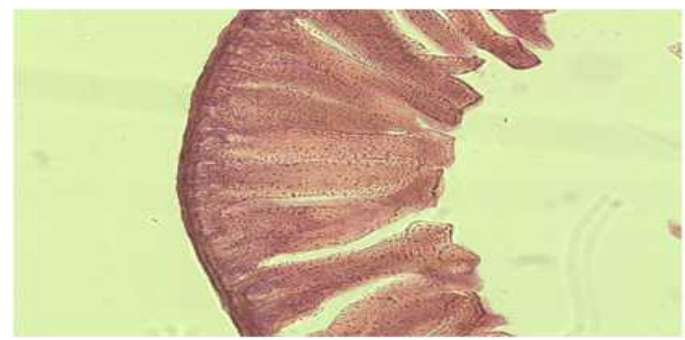

$3 \%$ supplementation of $95 \% \mathrm{EtOH}$

Fig. 6. Regressive staining of intestinal villi from high fat fed mouse. 
Table 6. Bacterial count on extracts additives treatments groups (Log CFU/ml)

\begin{tabular}{|c|c|c|c|c|c|c|c|}
\hline \multirow{3}{*}{ Items } & \multicolumn{7}{|c|}{ Treatments ${ }^{1)}$} \\
\hline & \multirow{2}{*}{ Control } & \multicolumn{3}{|c|}{$70 \% \mathrm{EtOH}$} & \multicolumn{3}{|c|}{$95 \% \mathrm{EtOH}$} \\
\hline & & $1 \%$ & $3 \%$ & $5 \%$ & $1 \%$ & $3 \%$ & $5 \%$ \\
\hline$T B C$ & $7.29 \pm 0.39^{\mathrm{a}}$ & $5.90 \pm 0.53^{\mathrm{bcd}}$ & $5.87 \pm 0.53^{\mathrm{bcd}}$ & $5.48 \pm 0.16^{\mathrm{d}}$ & $6.44 \pm 0.05^{b}$ & $6.23 \pm 0.12^{\mathrm{bc}}$ & $5.67 \pm 0.56^{\mathrm{cd}}$ \\
\hline Cl.pefringens & $4.11 \pm 0.09^{\mathrm{a}}$ & $4.01 \pm 0.03^{\mathrm{ab}}$ & $3.86 \pm 0.16^{\mathrm{bcd}}$ & $3.71 \pm 0.04^{\mathrm{de}}$ & $3.92 \pm 0.06^{\mathrm{bc}}$ & $3.80 \pm 0.17^{\text {cde }}$ & $3.64 \pm 0.05^{\mathrm{e}}$ \\
\hline$L A B$ & $5.59 \pm 0.30^{\mathrm{d}}$ & $5.86 \pm 0.04^{\mathrm{cd}}$ & $5.98 \pm 0.31^{\mathrm{cd}}$ & $6.86 \pm 0.84^{\mathrm{ab}}$ & $5.74 \pm 0.27^{\mathrm{cd}}$ & $6.35 \pm 0.07^{\mathrm{bc}}$ & $7.54 \pm 0.32^{\mathrm{a}}$ \\
\hline E.coli & $5.36 \pm 0.11^{\mathrm{a}}$ & $4.42 \pm 0.04^{b}$ & $4.37 \pm 0.14^{\mathrm{b}}$ & $3.84 \pm 0.16^{\mathrm{d}}$ & $4.36 \pm 0.07^{b}$ & $4.21 \pm 0.19 b^{c}$ & $4.03 \pm 0.02^{\mathrm{cd}}$ \\
\hline
\end{tabular}

${ }^{\mathrm{a}-\mathrm{d}}$ Mean $\pm \mathrm{SD}$ in the same column with different superscripts are significantly different at $p<0.05$.

$\mathrm{TBC}$, total bacterial counts; $\mathrm{LAB}$, lactic acid bacteria

차를 나타냈다. 소장의 융모를 광학현미경을 통해 측정한 결 과로 추출물 농도가 높아짐에 따라 융모가 넓어지고 길어짐을 Fig. 6에 나타내었다. 식이섬유의 섭취에 의한 소장의 구조 변 화는 식이섬유 섭취에 대한 그 기관의 적응현상으로 볼 수 있으며, 채식을 위주로 하는 사람들은 육식을 많이 하는 사람 들에 비해 소장의 길이가 길고 융모의 표면적이 넓어진다. Cummings 등은 식이섬유를 섭취시키면 융모의 표면적이 넓 어진다고 하였다[7]. 소장 villi 길이가 길어진다는 것은 소화의 흡수율이 개선된다는 것을 의미하고[11], 상위에 제시된 결과 중 높은 사료섭취량과 사료효율이 그것을 뒷받침 해준다. 위 와 같은 결과를 통해 양파껍질 추출물을 $5 \%$ 섭취할 경우 소장 이 무거워 지고 소장의 길이가 증가하는 유의적인 차이는 없 었으나 소장 villi의 길이가 유의적으로 길어져 $(p<0.05)$ 소화 흡수율의 개선효과가 있을 것으로 사료된다. Fang 등은 약용 식물 추출물의 급여를 통해 돼지의 ileum 점막상피의 융모길 이가 길어지고 그 길이와 영양소 흡수와 소화율에 정의 상환 관계가 있음을 보고하여[8] 본 연구결과와 유사한 결과를 나타 내었다.

\section{장내 미생물 측정 결과}

양파껍질 추출물을 농도별로 고지방사료에 첨가하여 ICR mouse에 급여한 후 장내미생물의 변화를 측정한 결과는 Table 6과 같다. Total bacterial count, Clostridium perfringens, Escherichia coli는 모든 처리구에서 농도 의존적으로 감소하였 고, total bacterial count 는70\% 주정 추출물 5\% 처리구가 $5.48 \pm 0.16 \mathrm{Log} \mathrm{CFU} / \mathrm{ml}$, Clostridium perfringens bacterial count 는 $95 \%$ 주정 추출물 $5 \%$ 처리구가 $3.64 \pm 0.05 \mathrm{CFU} / \mathrm{ml}$, Escherichia coli O157:H7는 70\% 주정 추출물 5\% 처리구가 $3.84 \pm 0.16 \mathrm{CFU} / \mathrm{ml}$ 으로 각 용매의 최고 추출물 첨가농도 처리 구들이 대조군에 비해 가장 큰 유의차를 나타내었다. 장내에 유익한 미생물로 잘 알려진 lactic acid bacteria는 모든 처리구 에서 농도 의존적으로 증가하는 경향을 보였고 $95 \%$ 주정 추출 물 $5 \%$ 급여구가 $7.54 \pm 0.32 \mathrm{CFU} / \mathrm{ml}$ 로 control에 비해 가장 높 은 균수를 나타내었다. 이는 양파 추출물내 존재하는 플라보 노이드 물질의 항균 특성으로 인해 장내 유익균을 보호하고 유해균의 억제를 통하여 장내 환경의 개선을 증진시키고 소장 의 융모발육을 증가시킨 것으로 판단된다. Fang 등은 약용식
물 추출물이 돼지의 장내 융모의 길이를 증가시켰다는 보고하 였으며[8] Hanczakowska와 Swiatkiewicz는 이들 약용식물의 추출물내 폴리페놀 성분들의 자유라디칼 소거능에 의한 항산 화 활성이 ileal 점막구조에 영향한 결과라고 하였는데[11] 본 연구결과와 유사함을 나타내었다. Oh 등은 사료 내 생균제 첨가효과로 대장균의 감소 경향이 나타난다고 하였는데[25] 상위에 제시된 결과로 미루어 보았을 때, 양파껍질 추출물은 추후 체중 조절기능식품의 소재로 활용가능성이 기대된다. 그 러나 가축의 사료에 첨가할 경우 장내 유해한 세균의 감소 및 유익한 세균을 증가 시킬 수 있는 생균제로서의 역할을 할 수 있을 것으로 기대되나 체중의 감소에 의한 생산성에 관한 문제가 해결되어야 사료 첨가제로서 활용가능성이 있을 것으로 판단된다.

\section{감사의 글}

본 연구는 강원대학교 수의대학 수의전염병학실험실의 지 원과 강원대학교 동물식품응용과학과의 학술연구비 지원으 로 이루어졌으며, 이에 감사드립니다.

\section{References}

1. Abe, N., Nemoto, A., Tsuchiya, Y., Hojo, H. and Hirota, A. 2000. Study of the 1,1'-diphenyl-2-pirylhydrazyl radical scavenging mechanism for a 2-pyrone compound. Biosci. Biotech Biochem 64, 306-333.

2. Bang, H. A. and Cho, J. S. 1998. Antioxidant effects on various solvent extracts from onion peel and onion flesh. $J$. Korean Diet. Assoc. 4, 14-19.

3. Bang, H. O. and Dyerberg, J. 1980. Plasma lipids and ischemic heart disease in Greenland Eskimos. Adv. Nutr. Res. 3, 1-9.

4. Bilyk, A., Cooper, P. I. and Sapers, G. M. 1984. Varietal differences in distribution of quercetin and kaempferol in onion (Allium cepa L.) tissue. J. Agric. Food Chem 32, 274-276.

5. Blios, M. C. 1958. Antioxidant determination by the use of a stable free radical. Nature 181, 1199-1200.

6. Bravo, E. 1998. Polyphenols: chemistry, dietary Sources, metabolism and nutritional significance. Nutr. Rev. 51, 317-333. 
7. Cummings, J. H. and Hill, M. J. 1976. Changes in fecal composition and colonic function due to cereal fiber. Am J. Clin. Nutr. 29, 1468-1473.

8. Fang, J., Yan, F. Y., Kong, X. F., Ruan, Z., Liu, Z. Q., Huang, R. L., Geng, M. M., Yang, F., Zhang, Y. Z., Li, P., Gong, J., Wu, G. Y., Fan, M. Z., Liu, Y. L., Hou, Y. Q. and Yin, Y. L. 2009. Dietary supplementation with Acanthopanax senticosus extract enhances gut health in weaning piglets. Livestock Sci. 123, 268-275.

9. Gareth, G., Laurence, T., Timoth, C., Brian, T. and Brian, S. 2002. Onions a global benefit to health. Phytother. Res. 16, 603-615.

10. Gordon, M. F. 1990. The mecanism of antioxidant action in vitra In B. J. F. Hudson, Food antioxidants, London: Elsevier Applied Science. pp: 1-18.

11. Hanczakowska, E. and Swiatkiewicz, M. 2012. Effect of herbal extracts on piglet performance and small intestinal epithelial villi. Czech J. Anim Sci. 57, 420-429.

12. Hermann, K. 1976. Flavonoids and flavones in food plants. A review. J. Food Tech 11, 433-448.

13. Ikegami, S., Tsuchihashi, F., Harada, H., Tsuchihashi, N., Nishide, E. and Innami, S. 1990. Effect of viscous indigestible polysaccharide on pancreatic-biliary secretion and digestive organs in rats. J. Nutr. 120, 353-360.

14. Jang, A., Ham, J. S., Kim, D. W., Chae, H. S., Kim, D. W., Kim, S. H., Seol, K. H., Oh, M. H. and Kim, D. H. 2011. Effect of quercetin and methoxylated quercetin on chicken thigh meat quality during cold storage. Korean J. Poult. Sci. 38, 265-273.

15. Jang, A., Park, J. E., Kim, S. H., Chae, H. S., Ham, J. S., Oh, M. H., Kim, H. W., Seol, K. H., Cho, S. H. and Kim, D. H. 2010. Effect of dietary supplementation of quercetin on oxidative stability of chicken thigh. Korean J. Poult. Sci. 37, 405-413.

16. Joo, S. T., Hur, J. I., Lee, J. R., Kim, D. H., Ha, Y. R. and Park, G. B. 1991. Influence of dietary onion peel on lipid oxidation, blood characteristics and antimutagenicity of pork during storage. Korean. J. Anim Sci. 41, 671-678.

17. KCDC. 2007. Report on 2007 Korea National Health and Nutrition Examination Survey (KNHANES IV). Korea Centers for Disease Control and Prevention, Seoul, Korea.

18. Kim, H. J., Bae, K. H., Lee, H. J., Eun, J. B. and Kim, M. K. 1999. Effect of Hesperidin extracted from tangerine peel on $\mathrm{Cd}$ and lipid metabolism and antioxidant capacity in rat. Korean J. Nut. 332, 137-149.

19. Kim, J. H. 1997. Anti-bacterial action of onion (Allium cepa L.) extracts against oral pathogenic bacteria. J. Nihon Univ. Sch Dent. 39, 136-141.

20. Kim, Y. J. 2010. Effects of dietary supplementation of garlic by-products on total phenol contents, DPPH radical scavenging activity, and physicochemical properties of chicken meat. Korean J. Food Sci. An. 30, 860-866.

21. Knhnau, J. 1976. The flavonoids a class of semiessential food components their role in human nutrition. World Rev. Nutr. Diet. 24, 117-120.

22. Lee, C. J., Kim, H. D., Choung, E. H., Suh, J. K., Park, C. W. and Ha, Y. L. 2000. Reduction effect of carcinogen - induced mouse epidermal and forestomach carcinogenesis by the extract of onion wastes. J. Korean Soc. Food Nut. 29, 525-530.

23. Marklund, S. and Marklund, G. 1974. Involvement of superoxide anion radical in the oxidation of pyrogallol and a convenient assay for superoxide dismutase. Eur. J. Biochem 47, 469-474.

24. Nam, S. H. and Kang, M. Y. 2003. Screening of antioxidative activity of Legume seeds. J. Korean Soc. Agric. Chem Biotechnol. 46, 32-38.

25. Oh, J. I., Kim, G. M., Ko, S. Y., Bae, I. H., Lee, S. S. and Yang, C. J. 2007. Effect of dietary Dandelion (Taraxzcum coreanum) and Dandelion fermented probiotics on productivity and meat quality of broilers. Korean J. Poult. Sci. 34, 319-327.

26. Park, H. S. 2011. Comparison of antioxidant activities of wild grape seed (Vitis coignetiea seed) extracts by solvents. Korean J. Culinary Res. 17, 270-279.

27. Park, P. S., Lee, B. R. and Lee, M. R. 1994. Effects of onion juice on ethanol - induced hepatic lipid peroxidation in rats. J. Korean Soc. Food Nut. 23, 750-756.

28. Poksay, K. S. and Schneeman, B. O. 1983. Pancreatic and intestinal response to dietary guar gum in rats. J. Nutr. 113, 1544-1549.

29. Salim, A. S. 1990. Oxygen-derived free radicals and the prevention of duodenal ulcer relapse. Am J. Med Sci. 300, 1-6.

30. SAS. 1995. SAS user's Guide ; Statstics. Statistical Analysis System. Inst. Inc., Cary, NC.

31. Son, J. Y., Son, H. S. and Cho, W. D. 1998. Antioxident effect of onion skin extract. Korean J. Soc. Food Sci. 14, 16-20.

32. Song, Y. S., Yang, J. L. and Suh, M. J. 1996. Effects of sodium alginate and cellulose on gastrointestinal physiology in rats. J. Korean Soc. Food Sci. Nutr. 25, 551-559.

33. Vogt, R. L. 2002. Escherichia coli O157:H7 outbreak associated with consumption of ground beef. Public Health Rep. 2, 174-178.

34. World Health Organization (WHO). 2003. World health report.

35. Yamaguchi, T., Takamura, H., Matoba, T. and Terao, J. 1998. HPLC method for evalution of the free radical_scavenging activity of food by 1,1'-diphenyl-2-pirylhydrazyl. Biosci. Biotech Biochem 62, 1201-1204.

36. Yen, G. H. and Chen, H. Y. 1995. Antioxidant activity of various tea extracts in relation to their anti mutagenicity. J. Agric. Food Chem 45, 27-32. 
초록 : 양파껍질 추출물 급여가 비만 유도쥐의 소장내 변화에 미치는 영향

박재인 · 김윤우 · 서태수 · 장애라*

(강원대학교 동물식품응용과학과)

본 연구는 양파껍질을 발효주정 에탄올 $70 \%$ 와 $95 \%$ 농도로 추출하여 항균활성, 항산화활성 및 비만쥐의 소화 기관에 미치는 영향에 대하여 알아보고자 실시하였다. 각 주정 추출물 $5 \%$ 는 E. coli와 Listeria monocytogens에서 유의적인 감소를 나타내었다. 각 주정 추출물 내 총 페놀함량은 각각 $166.89 \pm 0.03 \mathrm{mg} / \mathrm{g}$ 과 $160.89 \pm 0.13 \mathrm{mg} / \mathrm{g}$ 을 나타내었다. 항산화효과를 살펴본 결과 DPPH 라디칼 소거능과 SOD 유사 활성은 $100 \mathrm{ug} / \mathrm{ml}$ 의 농도에서 높은 수준을 나타내었다. 고지방식이를 급여하여 유도한 비만을 유도한 마우스에 $70 \%$ 와 $95 \%$ 주정으로 추출한 양파껍 질 추출물을 $1,3,5 \%$ 의 농도로 4 주간 급여한 후 체중, 사료섭취량, 사료효율, 소장무게, 길이 장내 융모의 길이, 소장 내 미생물수를 측정하였다. 각 주정으로 추출한 양파 추출물 $5 \%$ 의 농도로 급여하였을 때 대조군에 비해 체중이 유의적으로 낮은 수준을 나타내었으나 $(\beta<0.05)$ 사료섭취량은 증가함을 나타내었다. 실험동물 마우스 소장 의 무게와 길이는 양파 껍질추출물 급여에 따른 유의적인 변화는 보이지 않았으나 소장 융모의 길이는 대조군보 다 유의적으로 증가함을 나타내었다. 총균수, C.perfringenes와 E.coli는 5\%의 농도로 양파껍질 주정 추출물을 처리 했을 때 유의적으로 감소함을 나타내었으나 젖산균은 증가함을 나타내었다. 이러한 결과는 추후 부가적인 추가 연구가 필요하겠지만 $70 \%$ 와 $95 \%$ 의 주정으로 추출한 양파껍질 추출물을 $5 \%$ 수준으로 이용하면 체중조절 첨가제 로서 그리고 장의 건강을 증진시키기 위한 첨가제로 사용할 수 있는 잠재성이 있는 것으로 기대된다. 